\title{
Induction of $P R-10$ genes and metabolites in strawberry plants in response to Verticillium dahliae infection
}

\author{
Fatma Besbes, Ruth Habegger and Wilfried Schwab * (1)
}

\begin{abstract}
Background: The soil-borne vascular pathogen Verticillium dahliae causes severe wilt symptoms in a wide range of plants including strawberry (Fragaria $\times$ ananassa). To enhance our understanding of the effects of $V$. dahliae on the growth and development of $F . \times$ ananassa, the expression patterns of 21 PR-10 genes were investigated by qPCR analysis and metabolite changes were determined by LC-MS in in vitro F. $\times$ ananassa plants upon pathogen infection.

Results: The expression patterns of the 21 isoforms showed a wide range of responses. Four PR-10 genes were highly induced in leaves upon pathogen infection while eight members were significantly up-regulated in roots. A simultaneously induced expression in leaves and roots was detected for five PR-10 genes. Interestingly, two isoforms were expressed upon infection in all three tissues (leaves, roots and stems) while no induction was detected for two other members. Accumulation of antifungal catechin and epicatechin was detected upon pathogen infection in roots and stems at late stages, while caffeic acid and citric acid were observed only in infected roots. Production of abscisic acid, salicylic acid, jasmonic acid (JA), gibberellic acid and indole acetic acid (IAA) was induced in infected leaves and stems at early stages. IAA and JA were the sole hormones to be ascertained in infected roots at late stages.

Conclusions: The induction of several $P R-10$ genes upon infection of strawberry plants with $V$. dahliae suggest a role of $P R-10$ genes in the defense response against this pathogen. Production of phytohormones in the early stages of infection and antifungal metabolites in late stages suppose that they are implicated in this response. The results may possibly improve the control measures of the pathogen.
\end{abstract}

Keywords: Fragaria $\times$ ananassa, Strawberry, Verticillium dahliae, PR-10, Gene expression, GPCR

\section{Background}

Phytopathogenic fungi of the genus Verticillium cause billions of annual damage to agricultural crops worldwide [1]. The most studied species among the ten species currently grouped in the genus Verticillium sensu stricto is Verticillium dahliae because it is responsible for huge economic losses in crops in many regions of the world [2-4]. A plant species, which is highly susceptible to severe disease caused by the soil-borne pathogenic fungus $V$. dahliae is the cultivated strawberry (Fragaria $\times$ ananassa) plant. $V$. dahliae was first

\footnotetext{
* Correspondence: wilfried.schwab@tum.de

Biotechnology of Natural Products, Technische Universität München, Liesel-Beckmann-Str. 1, 85354 Freising, Germany
}

described from Dahlia sp. cv. Geiselher and has the largest impact as a pathogen as the probability of surviving infection by the Verticillium wilt fungus to produce a crop is greatly reduced and the control of Verticillium wilt is difficult and costly [5-7]. In the absence of a suitable plant host, $V$. dahliae remain dormant in the soil for years by means of small melanized resting structures (microsclerotia) and germinate only in the proximity of a suitable host [8].

The life cycle of the phytopathogenic fungi comprises three vegetative phases: dormant, parasitic and saprophytic. In the dormant phase, the nitrogen- and carbon-rich root exudates [9] stimulate germination of microsclerotia, which are long lasting multicellular structures. These structures enable Verticillium spp. to infect

(c) The Author(s). 2019 Open Access This article is distributed under the terms of the Creative Commons Attribution 4.0 International License (http://creativecommons.org/licenses/by/4.0/), which permits unrestricted use, distribution, and 
susceptible plants and enter their parasitic stage. Infection occurs either at the sites of lateral root formation or at the root tip [10]. After infiltration of the vascular cylinder the phytopathogenic fungi begins to form conidia, which travel in the xylem system [11, 12]. The plant becomes increasingly colonized, begins to wilt and develops typical symptoms of necrosis. The fungus enters a limited saprophytic growth phase in which microsclerotia are formed. When released into the soil the microsclerotia can survive for 10-15 years [8]. Monocyclic pathogens such as $V$. dahliae go through only one round of disease and inoculum production per growing season and do not need to repeat the cycle in subsequent years $[1,13]$.

Plants can respond to both biotic and abiotic stresses. Pathogenesis-related (PR) proteins, including family 10 proteins (PR-10), are induced under biotic and abiotic stress and are therefore involved in plant defense [14]. The PR-proteins are expressed in many plant species e.g. after fungal infection during induction of resistance. In cotton, early stage expression of PR-10 combined with phytoalexin production contributes to Verticillium wilt resistance [15]. PR-10 proteins are encoded by multigene families and are constitutively expressed in different organs. Numerous functions are assigned to this protein family [16].

Despite several studies and investigations, the specific role of individual PR-10 members remains unclear. This work aimed to investigate the molecular interplay between in vitro strawberry plants and the $V$. dahliae pathogen in order to get molecular evidence about strawberry defense response, to identify induced $P R-10$ genes upon pathogen infection and to achieve insight into the hormonal response in strawberry. The purpose of the current study was to contribute to the understanding of the function of the $P R-10$ isoforms.

\section{Results}

\section{Visual evaluation of disease severity and fungal propagation}

$F . \times$ ananassa in vitro plants were artificially inoculated with the isolate E650 of $V$. dahliae (Additional file 1). At all sampling time points, plants were visually assessed for the appearance of foliar symptoms using a $0-5$ scale according to [17]. The scale is based on the percentage of diseased leaf area. Disease symptoms developed gradually and became visible 20 days post Verticillium inoculation. Scale 2 (10-25\% of symptomatic leaf area) was attributed to plants at $20 \mathrm{dpi}$ (days post infection) and scale 5 (75-100\% of symptomatic leaf area) for plants at $30 \mathrm{dpi}$. For control and infected plants during the first 20 days, no symptoms were observed and therefore scale 0 was assigned (Fig. 1). Samples were also evaluated based on color modification after methanol extraction of lyophilized tissues (Fig. 1). Comparison of Verticillium infected roots and the control demonstrated that the color was yellowish at the first day and became progressively light brown at $30 \mathrm{dpi}$ for the infected roots and yellowish brown for the control. Similarly, a color change was visible between $1 \mathrm{dpi}$ (fluorescent green) and $30 \mathrm{dpi}$ (fluorescent yellowish green) in infected stems but not for the control tissue whereas in infected leaves, the unique color change occurred at $20 \mathrm{dpi}$ (dark green) and 30 dpi (light green) (Fig. 1). No color change was detected for the control leaves.

\section{Validation of primer design}

BLAST analysis identified 21 PR-10 genes in the genome sequence of $F$. vesca ([18]; Additional file 2). Because of the high sequence similarity between the 21 PR-10 isoforms (nearly $70 \%$ of pairwise nucleotide identity), specific primers for quantitative polymerse chain reaction (qPCR) were designed using the 5' UTR and 3' UTR regions (Additional file 3). The qPCR analysis of PR-10.01-03 was performed using the specific primer pairs as described [19]. For all other PR-10 genes specific primers were designed using the $5^{\prime}$ UTR, except for PR-10.09, PR-10.14, PR-10-17 and PR-10.20. For efficient amplification in $\mathrm{qPCR}$, primers used in this study produced amplicons of sizes less than $200 \mathrm{bp}$. Except for the reverse primer of $P R-10.05$, which had a length of $19 \mathrm{bp}$, all the remaining $P R-10$ primers showed sizes between 20 and $27 \mathrm{bp}$. The GC content varied from 32 to $65 \%$. In addition, apart from the primer of $P R-10.16$, which had a melting temperature $(\mathrm{Tm})$ of $56^{\circ} \mathrm{C}, \mathrm{Tm}$ for the primers of the remaining PR-10 isoforms were between $59^{\circ} \mathrm{C}$ and $64{ }^{\circ} \mathrm{C}$. The gene specificity of the designed primers was confirmed by Basic Local Alignment Search Tool (BLAST) analysis of the primer sequences (forward and reverse) of each of the $21 P R-10$ isoforms. Each primer perfectly matched only the sequence of the target gene. Even though the primers were designed on the PR-10 sequences from $F$. vesca, they also produced respective amplicons from $F . \times$ ananassa. The melting curves recorded after the transcript analyses showed single distinct peaks indicating high specificity for all $P R-10$ isoforms.

\section{Quantitative real-time PCR analysis of $21 P R-10$ genes in response to Verticillium infection}

To examine the effect of pathogen infection on the expression of $P R-10$ genes, in vitro cultivated strawberry plants were infected with $V$. dahliae. Samples were taken at defined intervals post infection (dpi). Non-infected plants served as control. Values were calculated as fold change of each sample relative to a reference gene (FaRIB413). The fold changes of each transcript (relative values) upon Verticillium infection were calculated and represented for each Fra a 1 gene. The expression 


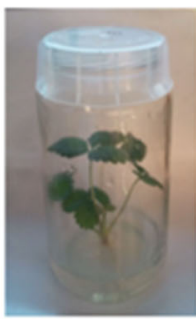

Day 1

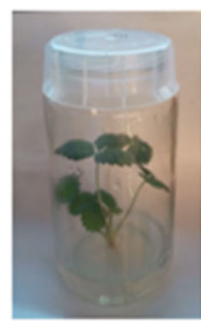

Day 5

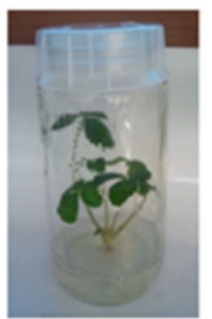

Day 10

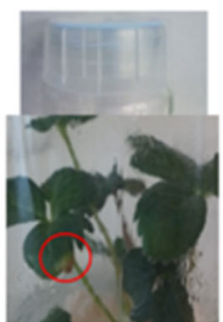

Day 20

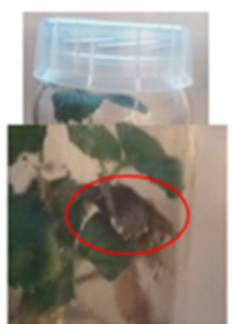

Day 30
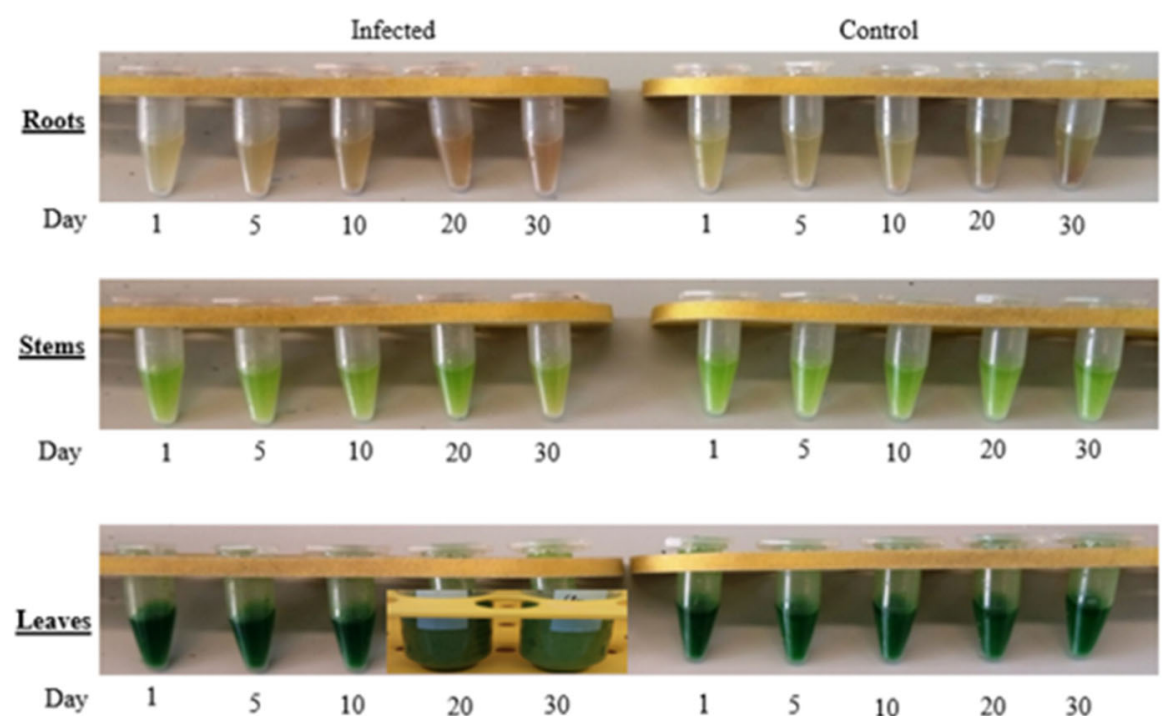

Fig. 1 Development of disease symptoms in in vitro plants infected with $V$. dahliae at different time points (1, 5, 10, 20, and 30 days) and comparison of methanol extracts of lyophilized tissues from control and infected organs at different time points post $V$. dahliae infection $(1,5,10$, 20 and 30 days)

pattern of $21 P R-10$ isoforms in different tissues (leaves, stems and roots) of the strawberry plants, after infection with $V$. dahliae showed a wide range of response. PR-10.03 (11.4 fold relative expression at $30 \mathrm{dpi}$ ) and PR-10.16 (219.9 fold rel. Exp. at $20 \mathrm{dpi}$ ) were significantly upregulated in leaves after pathogen infection (Fig. 2). This induction increased through the time and reached a maximum after 20 to 30 days of infection. For PR-10.21 (2.7 fold rel. Exp. at $1 \mathrm{dpi}$ ), the highest induction level was detected in leaves already after 1 day of infection followed by a steady decrease until the 10th day. For PR-10.11 (1.4 fold rel. Exp. at $1 \mathrm{dpi}$ ), the induction of expression was also significant in leaves at day 1 post inoculation (Fig. 2).

PR-10.06, PR-10.08 and PR-10.17 were highly expressed in roots after pathogen infection (Fig. 3). There was an up to 36.1 fold relative transcript level for PR-10.06, 31.3 fold rel. Exp. for PR-10.08, and 140 fold rel. Exp. for $P R-10.17$ at $10 \mathrm{dpi}$. The induction was more relevant at day 5 for $P R-10.06$ and $P R-10.08$ and at day 10 for $P R-10.17$. Interestingly, a quick and prominent upregulation was also observed in roots for $P R-10.02$
(4.2 fold rel. Exp.) at 1 dpi which declined slightly over time. Similarly, $P R-10.20$ (14.8 fold rel. Exp. at $10 \mathrm{dpi}$ ) and PR-10.14 (19.8 fold rel. Exp. at $10 \mathrm{dpi}$ ) were highly induced in roots but the maximum peak occurred at day 10. Moreover, the expression patterns of PR-10.15 (9.0 fold rel. Exp. at $5 \mathrm{dpi}$ ) and PR-10.18 (1.7 fold rel. Exp. at $5 \mathrm{dpi}$ ) were similar in roots and increased from day 1 to day 5 followed by a diminution until day 30 (Fig. 3).

Furthermore, PR-10.04, PR-10.01, PR-10.12, PR-10.19 and $P R-10.10$ were strongly induced in leaves and roots simultaneously (Fig. 4). For the first three genes, the induction was more relevant in leaves after $20 \mathrm{dpi}$. There was an up to 14.0 fold rel. Exp. at $30 \mathrm{dpi}$ for PR-10.04, 1.6 fold rel. Exp. at $30 \mathrm{dpi}$ for $P R-10.01$ and 5.0 fold rel. Exp. also at $30 \mathrm{dpi}$ for $P R-10.12$ in leaves. In roots, an upregulation was detected at day 1 for PR-10.04 (4.1 fold rel. Exp.) followed by a decrease until day 30, whereas a strong induction of expression in infected roots was observed after 10 days for $P R-10.01$ (1.3 fold rel. Exp.) and 5 days for PR-10.12 (6.4 fold rel. Exp.). For PR-10.19, there was a high expression level in leaves namely at day 20 (4.3 fold rel. Exp.) and day 30 (7.9 fold rel. Exp.) post 

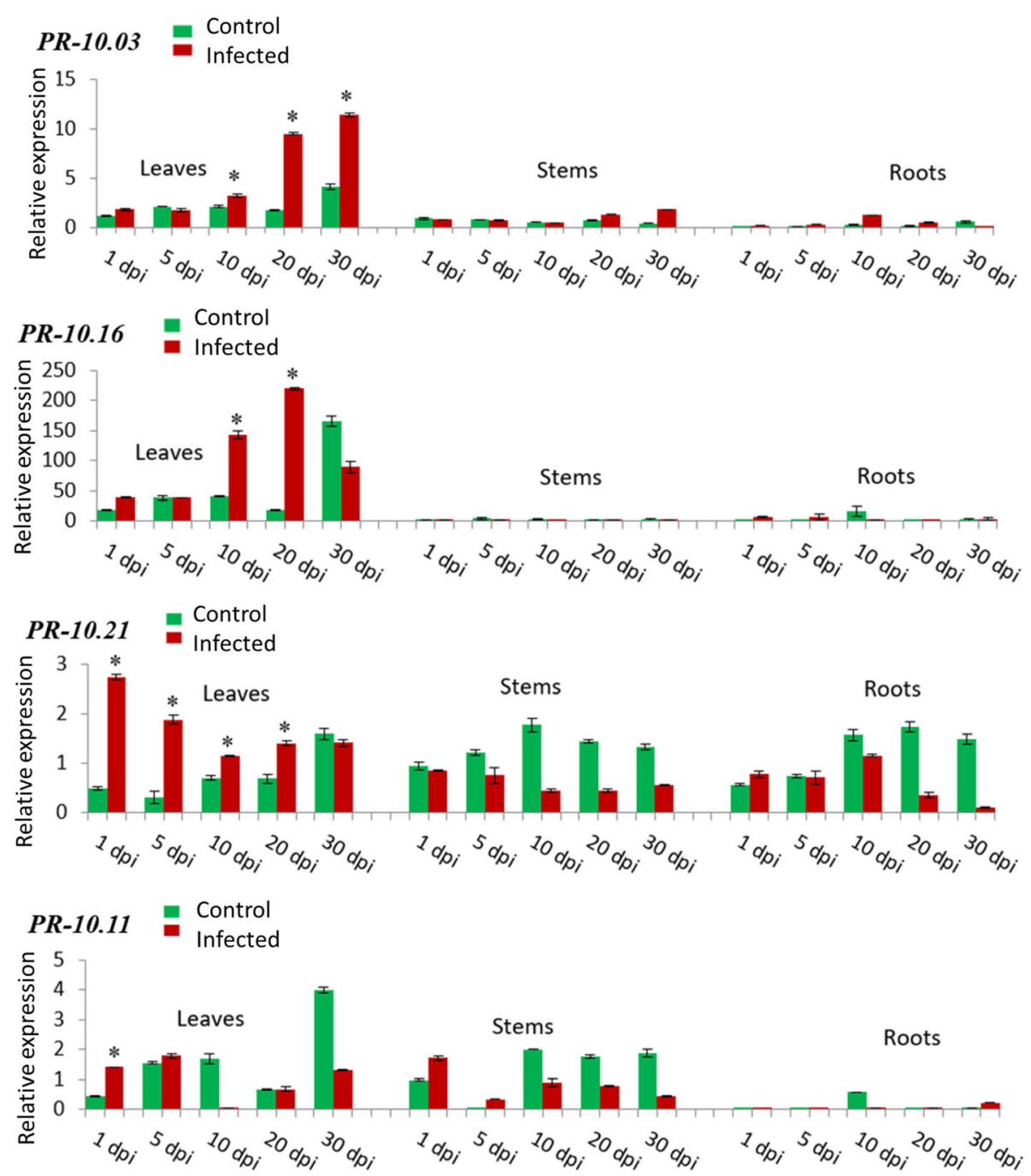

Fig. 2 Relative transcript levels determined by qPCR of PR-10.03, PR-10.11, PR-10.16 and PR-10.21, which are highly induced in leaves. Strawberry plants were infected with $V$. dahliae and the relative transcript levels were normalized to the control stem at $1 \mathrm{dpi}$ (set to one). The expression levels in the tissues were measured at 1, 5, 10, 20, and 30 dpi (days post infection). Green bars represent the control while red bars represent infected tissues. The mean values $( \pm \mathrm{SD}$ ) were obtained from five biological replicates and are shown as relative changes. Asterisks represent significant induction of a gene after statistical comparison with the transcript abundance of the control sample using the Tukey test. FaRIB413

was used as a housekeeping gene for normalization

pathogen inoculation while in roots a progressive induction was detected until the 10th day (12.7 fold rel. Exp.) followed directly by a severe decline from the 20th day (3.4 fold rel. Exp.) of infection. PR-10.10 showed also a considerable upregulation in leaves at the first 5 days of infection (2.0 fold rel. Exp.) but this increase gradually diminished in the course of time. In roots, this gene started to be induced from day 1 (0.9 fold rel. Exp.) until day 10 (1.0 fold rel. Exp.) followed by a drastic decrease at day 30 (0.1 fold rel. Exp.) (Fig. 4).

Interestingly, the expression of $P R-10.13$ and $P R-10.09$ was induced in all three tissues at the same time (Fig. 5). In leaves, the expression pattern of both genes was very similar. It decreased progressively during the first 10 days post inoculation and augmented again until the 30th day (7.5 fold rel. Exp. for PR-10.13 and 18.4 fold rel. Exp. for $P R$-10.09). In addition, those two genes were identically induced in roots. A gradual upregulation was observed until the 10th day of infection (15.8 fold rel. Exp. for PR-10.13 and 17 fold rel. Exp. for PR-10.09) followed by a progressive diminution of expression until day 30 (0.2 fold rel. Exp. for $P R-10.13$ and 3.3 fold rel. Exp. for PR-10.09). Moreover, $P R-10.13$ and PR-10.09 were the only two genes which were induced in stems. A steady decrease in the gene expression was detected for PR-10.13 from the first day (3.3 fold rel. Exp.) and until the 30th day while for $P R-10.09$ there were two peaks of expression, one peak at the 10th day (8.2 fold rel. Exp.) 


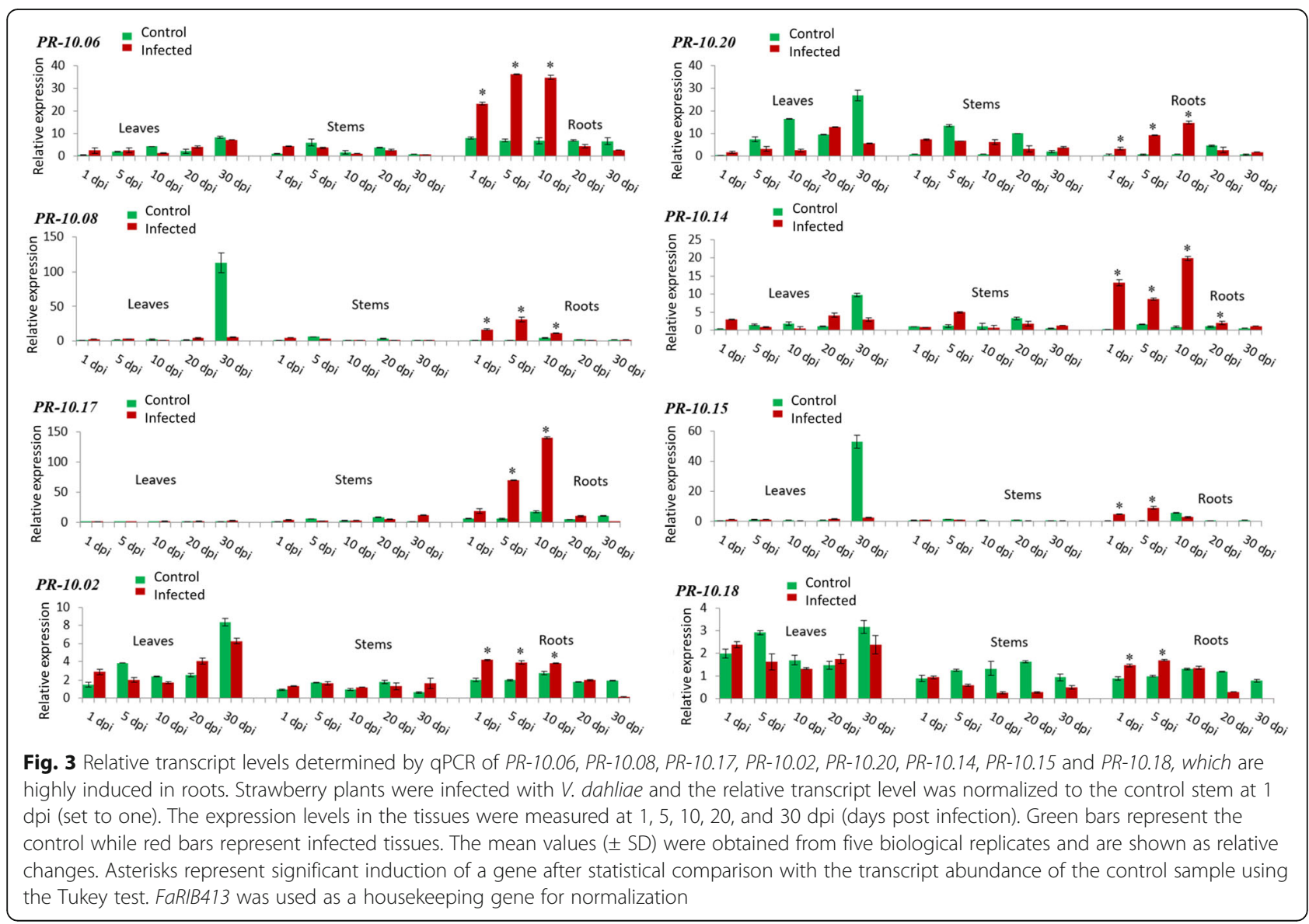

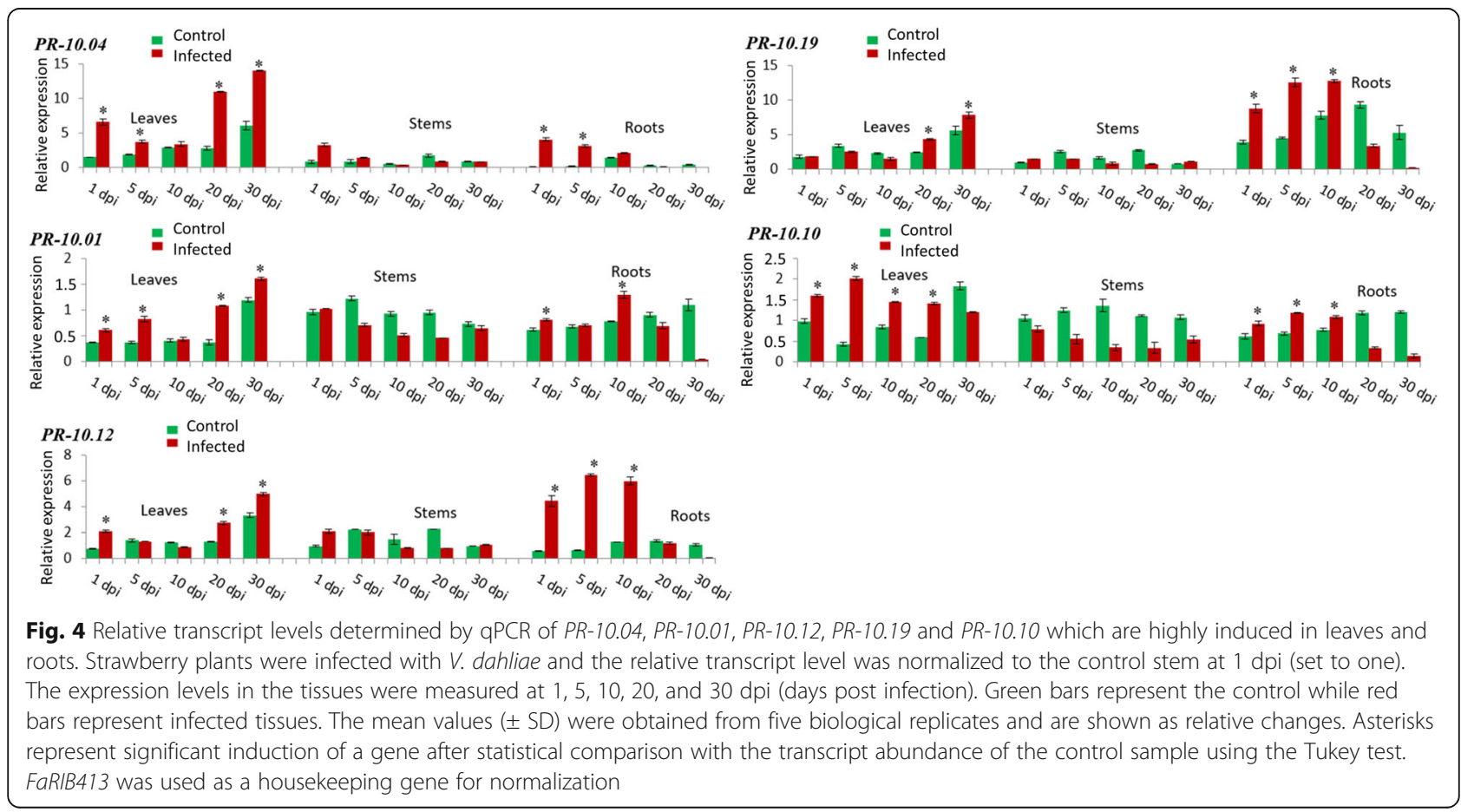



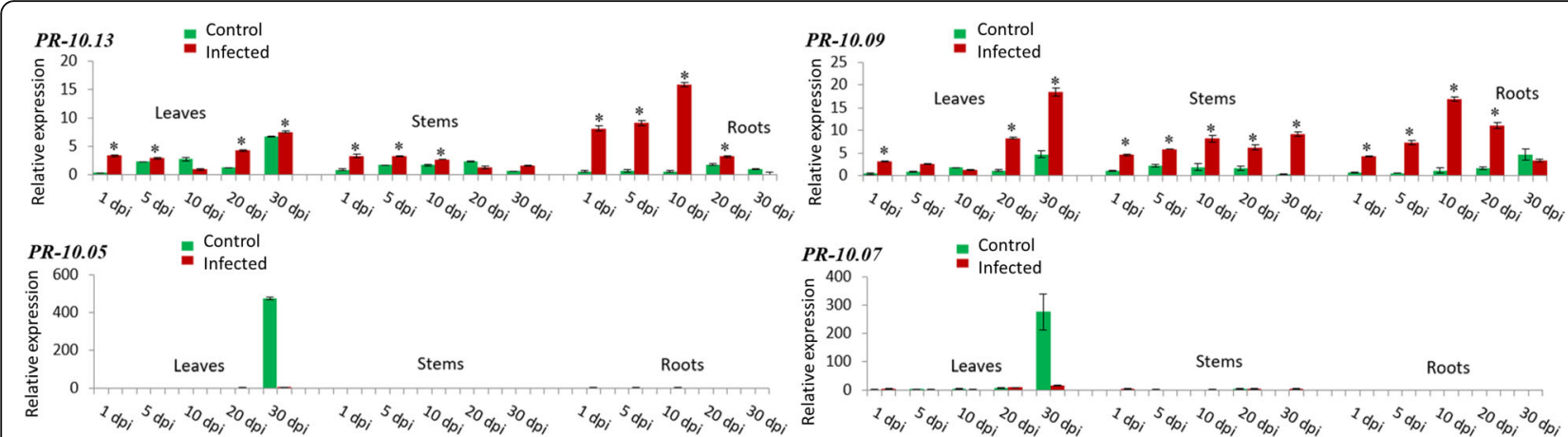

Fig. 5 Relative transcript levels determined by qPCR of PR-10.13 and PR-10.09, which are highly induced in leaves, roots, and stems and relative transcript levels of PR-10.05 and PR-10.07 which indicated no induction for both isoforms. Strawberry plants were infected with $\mathrm{V}$. dahliae and the relative transcript level was normalized to the control stem at $1 \mathrm{dpi}$ (set to one). The expression levels in the tissues were measured at 1, 5, 10, 20, and $30 \mathrm{dpi}$ (days post infection). Green bars represent the control while red bars represent infected tissues. The mean values ( \pm SD) were obtained from five biological replicates and are shown as relative changes. Asterisks represent significant induction of a gene after statistical comparison with the transcript abundance of the control sample using the Tukey test. FaRIB413 was used as a housekeeping gene for normalization

and the second peak at the 30th day (9.2 fold rel. Exp.) (Fig. 5). Interestingly, no induction of gene expression was detected in infected tissues for $P R-10.05$ and PR-10.07 (Fig. 5).

Altogether, a huge variation in transcript levels of the 21 isoforms was observed in the investigated $F . \times$ ananassa organs (leaves, stems and roots). The qPCR analysis indicated a clear upregulation of 19 isoforms after Verticillium infection and a different pattern of expression depending upon the analyzed strawberry tissue. The highest levels of induction were detected at later time point for leaves (20 to 30 days post pathogen inoculation) and early stage in roots (first 10 days post pathogen inoculation) (Additional file 4).

\section{Liquid chromatography-mass spectrometry (LC-MS) analysis}

In order to test whether plant metabolites are involved in the defense response toward Verticillium infection in strawberry in vitro plants, tissues used for qPCR were also analyzed by LC-MS (Fig. 6). Metabolites such as catechin and epicatechin accumulated in stems and roots over time in infected tissues and exceeded the levels in the control plants considerably. Caffeic acid and citric acid were observed mainly in infected roots at 30 dpi. Tryptophan was observed in infected leaves and stems at $1 \mathrm{dpi}$ as well as at late stage in infected leaves and roots (20-30 dpi). Glutathione in its reduced form (GSH) was mainly detected in control stems and roots and at $1 \mathrm{dpi}$ in infected leaves. Furthermore, the implication of some phytohormones on strawberry defense was also tested. Five plant hormones were identified by LC-MS. Abscisic acid (ABA), salicylic acid (SA), jasmonic acid (JA), and gibberellic acid (GA) accumulated in infected leaves at $5 \mathrm{dpi}$ and at $10 \mathrm{dpi}$ for indole-3-acetic acid (IAA). The five phytohormones were also detected in infected stems at various time points: during the first $5 \mathrm{dpi}$ for SA, IAA and GA, and during the first 10 days post inoculation for JA. Likewise, ABA was identified during the first 10 days in infected stems with a peak at $30 \mathrm{dpi}$. IAA and JA were the unique hormones to be discerned in infected roots at tardy stages (20 and $30 \mathrm{dpi})$ (Fig. 6).

\section{Discussion}

\section{$P R$-10 gene expression}

The present study clearly demonstrated that the expression of various $P R-10$ genes was induced by Verticillium infection in in vitro strawberry plants. $P R-10.03$, $P R-10.11, P R-10.16$ and $P R-10.21$ were significantly induced in leaves (Fig. 2). The gene expression levels peaked in leaves $20-30 \mathrm{dpi}$ for $P R-10.03$ and $P R-10.16$ and from 1 to $5 \mathrm{dpi}$ for $P R-10.21$ and $P R-10.11$. Apoplastic proteome analysis in leaves of oilseed rape infected with $V$. longisporum revealed the up-regulation of PR-2 ( $\beta$-1,3-glucanase), PR-3 (chitinase) and PR-4 (chitinase) [20]. In lettuce infected with $V$. dahliae, $P R-3$ and $P R-5$ (thaumatin-like) genes were expressed only in symptomatic leaves harvested 3 weeks after infection [21]. Thus, infection by Verticillium caused the up-regulation of multiple PR genes in leaves including $P R-2, P R-3, P R-4$ [20], $P R-5$ [21], and $P R-10$ [this study].

Transcription of PR-10.02, PR-10.06, PR-10.08, PR-10.14, PR-10.15, PR-10.17, PR-10.18 and PR-10.20 was strongly induced in roots upon Verticillium infection. Notably, $P R-10.17$ was exclusively transcribed in roots with the highest expression value within the $21 P R-10$ isoforms (Fig. 3). The upregulation was mainly observed during the first 10 days post inoculation. Although plant roots are in close contact with a diversity of soil microorganisms, interactions 


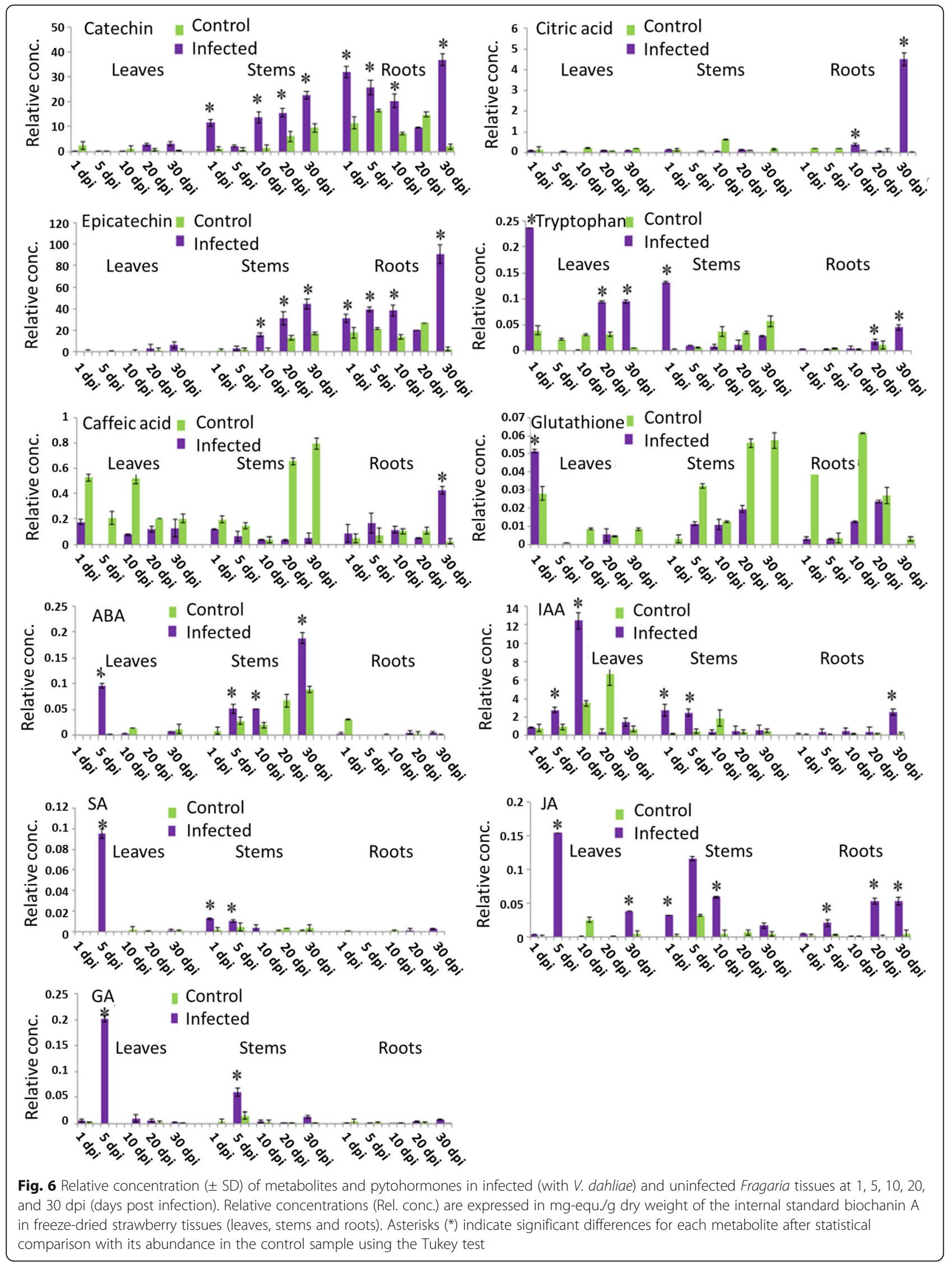


between them are still poorly studied [22, 23]. Recently, Arabidopsis thaliana was used as a host model for $V$. dahliae $[24,25]$ and $V$. longisporum [26] to analyze the interaction between roots and vascular pathogens. In $A$. thaliana roots infected with $V$. longisporum, genes involved in the production of tryptophan-derived secondary metabolites showed the highest transcript levels at 8 dpi [27]. Similarly, in our study, a peak of expression in roots was reached around $10 \mathrm{dpi}$ suggesting that the fungus is spreading over time until a decline of expression is reached at $30 \mathrm{dpi}$. This decrease is probably due to plant resistant responses followed by fungus elimina tion around $30 \mathrm{dpi}$. Pectinaceous gels, formed in xylem vessels of plants infected with Fusarium oxysporum, are considered an effective defense system, as pathogen colonization of the upper parts of stem and leaves is blocked. The pathogen remains in the infected roots and cannot spread [28]. Thus, according to this study and all the cited results, the high level of some PR-10 proteins in roots is probably part of a constitutive defense mechanism in this plant organ that is most exposed to environmental stress.

Interestingly, PR-10.01, PR-10.04, PR-10.10, PR-10.12 and $P R-10.19$ isoforms were considerably expressed in both roots (early stage) and leaves (late stage) and hence correlated with the time course of infestation (Fig. 4). This finding is also in accordance with the induction of $P R-10 c$ in leaves and roots of birch in response to oxidative stress [29]. Overall, the expression levels of the 17 above-cited $P R-10$ genes revealed that leaves and roots differ considerably in executing their temporal defense responses.

A striking expression was observed for $P R-10.13$ and $P R-10.09$, which were induced in all three tissues (leaves, roots and stems) simultaneously (Fig. 5). Several studies showed that Verticillium species enter the xylem vessels of the root and start sporulating after 2 to 5 dpi followed by a colonization of stem vessels few days later $[11,30]$. In Verticillium-infected hop stems [31], the fungal biomass increased through time in accordance with the transcript level of $P R-10.09$ in stems while the expression of $P R-10.13$ decreased steadily until $30 \mathrm{dpi}$. Also in stems of tomato (Solanum lycopersicum) infected with $V$. dahliae, the expression pattern of two PR-genes Ve1 and $V e 2$ encoding cell surface receptor proteins of the extracellular leucine-rich repeat receptor-like protein class of disease resistance proteins revealed that both genes exhibited high transcript levels 10-12 dpi in the susceptible isolines [32]. In Verticillium-infected tomatoes, the host compatibility (susceptibility) or incompatibility (resistance) with Verticillium appeared to be determined in stems [33, 34]. Moreover, during Verticillium colonization in this tissue, fungal elimination predominates because the resistant cultivar plant is able to activate defense responses faster [30, 35] while in the susceptible cultivar the pathogen escapes from this elimination and spreads inside the plants vascular system $[11,36]$.

In strawberry, both resistance and tolerance can enhance the global performance of different genotypes in the presence of $V$. dahliae but tolerance may be less stable over the course of a season [37]. Contrary to plant disease resistance, which protect plants from pathogen attack, plant disease tolerance is a specific phenomenon that includes down-regulation of genes associated with development of symptoms [38]. Most of the 41 evaluated strawberry genotypes from the University of California breeding program were identified as highly susceptible to $V$. dahliae however, eleven strawberry $(F . \times$ ananassa $)$ genotypes were designated as resistant to Verticillium wilt $[37,39]$. Strawberry resistance to a variety of pathogens has been bred into commercial varieties as a polygenic trait and has been reported to be quantitatively inherited [40]. The nonappearance of symptoms despite high levels of $V$. dahliae inoculum could result from a decreased incidence of systemic infection and from reduced symptom expression after pathogen entry into the xylem. The roles of $P R$-genes in the $V$. dahliae resistant genotypes has not yet been well studied.

In the present work, after Verticillium inoculation, a visual assessment of the foliar symptoms of $F . \times$ ananassa in vitro plants was performed. The scale employed for the visual assessment of the disease was based on the percentage of symptomatic leaf area. The strawberry plants seemed to be "healthy" during the first $20 \mathrm{dpi}$ (class 0 ) since no visible foliar wilting symptoms were observed. The diffusion of strawberry leaf symptoms began with class 2 equivalent to $10-25 \%$ of symptomatic leaf area at $20 \mathrm{dpi}$ and only after 10 additional days, the fungus was able to colonize almost the totality (75$100 \%$ ) of the leaf surface producing necrotic leaves, which were sometimes stunted in stature. The disease severity was considerable beyond $36 \mathrm{dpi}$ as the in vitro plants faded completely resulting in wilting and plant death, which explained consequently, why plant material for gene expression analysis was not more recoverable after this time point. Similarly, the response to the infection caused by $V$. dahliae in two micropropagated $F$. $\times$ ananassa cultivars became evident only after $15 \mathrm{dpi}$ and, differently to our results, the highest percentage of totally chlorotic microplants was obtained at $75 \mathrm{dpi}$ for both subclones 'Filon' and 'Teresa' [41]. While our findings clearly demonstrated an initiation of transcriptional responses in leaves, roots and stems during invasion by the Verticillium fungus for nineteen of the PR-10 genes, PR-10.05 and PR-10.07 seemed to escape from the fungus colonization since no induction was detected in any tissue for both genes. 
Studying defense gene expression implies the use of a suitable host-pathogen model system and respective culture conditions. In strawberry, many researchers have applied in vitro screening systems to obtain plants resistant or tolerant to Rhizoctonia fragariae and Botrytis cinerea [42], Colletotrichum acutatum [43], Fusarium oxysporum [44], Phytophthora cactorum, P. fragariae [45] and $V$. dahliae [46]. In vitro selection, the technique used in this work, is a useful tool in identifying plants resistant or tolerant to stresses produced by phytotoxins from pathogens, cold temperature and salt toxicity [47]. Susceptibility of strawberry cultivars and breeding lines to infection by $V$. dahliae under in vitro conditions was similar to their response to infection in field conditions [48].

\section{Tissues analysis by LC-UV-ESI-MS Secondary metabolites}

Flavan-3-ols such as catechin and epicatechin accumulated in infected stems and roots especially at late stages after infection by the fungus $V$. dahliae (Fig. 6). This result suggested that increased production of catechin and epicatechin during Verticillium inoculation exercise a protective role in suppressing fungal infection. (+)-Catechin, which already pre-existed in strawberry leaves, inhibited Alternaria alternate and induction of resistance response in the strawberry leaf to this fungus provoked the accumulation of (+)-catechin [49]. Accumulation of catechinderived procyanidins was fundamental to inhibit the growth of Botrytis cinerea in immature strawberry fruits [50]. Moreover, in Centaurea maculosa or spotted knapweed, $( \pm)$-catechin has been reported to be released from its roots [51] showing an inhibitory effect on soil microbial activity [52]. Likewise, Veluri et al. [53] reported an antimicrobial and antifungal effect of (+)-catechin to some soil strains (Xanthomonas campestris, Agrobacterium radiobacter, Erwinia carotovora, and Erwinia amylovora). Such activities of $(+)$-catechin on certain soil microbial isolates were not detected for the (-)-enantiomer of catechin, which was revealed to be phytotoxic [54]. Besides, it has been reported that epicatechin was able to inhibit lipoxygenase from Colletotrichum gloeosporioides, which inactivated antifungal dienes (1-acetoxy-2-hydroxy-4-oxoheneicosa-12, 15-diene) formed during the ripening of avocado [55]. The flavan-3-ol, which is present in unripe fruit at high concentration, might also be involved in the resistance of avocado fruits by inhibiting the pectate lyase activity of C. gloeosporioides [56]. The flavan-3-ols catechin and epicatechin have also anti-oxidative and radical-scavenging activities that exceed those of ascorbic acid, $\alpha$-tocopherol and other phenolics [57].

Contrary to the caffeic acid levels, which significantly decreased in tomato roots upon Arbuscular mycorrhizal colonization [58], levels of caffeic acid were induced in F. $\times$ ananassa infected roots particularly after $30 \mathrm{dpi}$ in this study. Caffeic acid, which plays a role in plant defense reactions, showed strong in vitro antimicrobial activity against numerous fungi including $V$. dahliae. It has been shown that this antioxidant compound is increased in Verticillium-infected cotton plants [59] and in potato with a differential accumulation in roots and stems [60]. In pepper roots, the fungus Fusarium oxysporum stimulated the biosynthesis of caffeic acid and primed that of chlorogenic acid [61].

Similarly, accumulation of citric acid was induced at late stage in infected roots (30 dpi) supporting the hypothesis that this acid affects growth and health of the plant host. Root secretion of citric acid was enhanced in Fusarium oxysporum $f$. sp. cucumerinum-infected cucumber plants and citric acid acted as a chemoattractant in this process [62]. Root exudates from tomato, cucumber and sweet pepper plants grown under gnotobiotic conditions contained higher total amounts of organic acids (citric acid) than of carbohydrates [63]. The rhizobial microflora affects the composition of root exudates as application of the bacterial biocontrol strain Pseudomonas fluorescens to tomato roots led to reduced levels of succinic acid, whereas the concentration of citric acid increased [64].

In this work, the levels of tryptophan, another strawberry plant constituent, in infected tissues exceeded the level in control plants after $1 \mathrm{dpi}$ in leaves and stems, and 20-30 dpi in roots. It appears that strawberry plants have evolved various defense mechanisms against biotic stress, including the production of primary and secondary metabolites, which act as defense compounds. Leaves of $F . \times$ ananassa inoculated with the angular leaf spot bacterium, Xanthomonas fragariae, produced high level of tryptophan, which is a precursor of aromatic secondary metabolites [65]. The tryptophan pathway plays also an important role in the defense responses against pathogenic infection in Arabidopsis root [27] as well as in rice [66].

The accumulation of the reduced form of glutathione upon fungal infection was exclusively observed in this work in infected leaves after 1 dpi revealing a quick response to Verticillium infection. Glutathione probably plays a role in the plant cells response to physical as well as biological stresses. Glutathione is a major cellular antioxidant and both glutathione metabolism and levels influence cellular defenses [67]. In most plant tissues, glutathione is predominantly present in its reduced form (GSH) but the oxidized disulphide form of glutathione (GSSG) can also be detected. GSH and its homologues are considered as essential components in plant cell by participating in the elimination of reactive oxygen species (ROS) via thiol-disulphide redox reactions and in detoxification of various xenobiotics by conjugation reactions $[68,69]$. GSH is involved in response to oxidative and abiotic stress, which rapidly accumulated after 
fungal attack [70]. Participation of GSH in antioxidative defense reactions and detoxification appeared to be the principal role of GSH in plant tissues either by direct reactions with reactive oxygen species or through the ascorbate-GSH cycle [70]. Moreover, both GSH and GSSG elicited the phytoalexin response in cell-suspension cultures of bean but had no effect in alfalfa [71]. A decline in GSH content in oat leaves infected by the fungal pathogen Drechslera approximately 2 days post-inoculation indicatied an increased demand for detoxification of reactive oxygen species in the early stages of pathogenesis [72]. Similarly, except for a high level of GSH at $1 \mathrm{dpi}$ in infected leaves, lower levels of GSH were detected in this work in infected tissues in comparison with the controls leading. This led to the conclusion that the infected leaf tissue showed a reduced capacity to resist oxidative stress and to repair damage. The changes in GSH level was also quantified in tomato leaves carrying either the genes $\mathrm{Cf}-2$ or Cf- 9 conferring resistance against the fungal pathogen Cladosporium fulvum [73]. The total glutathione level increased 2 to $8 \mathrm{~h}$ after the injection of elicitor into the leaves and that $87 \%$ of this accumulation was attributed to the GSSG form. Significant increases in the foliar GSH levels were also observed in different oat lines (Avena sativa) $24 \mathrm{~h}$ after infection with $B$. graminis $f . s p$. Avenae [74] and in resistant tobacco (Nicotiana tabacum $L c v$. Xanthi-nc) plants infected with Tobacco Mosaic Virus (TMV) [75].

\section{Phytohormones}

Phytohormones such as ABA, SA, GA, IAA and JA are major signaling molecules in plants during stress response and their levels have been investigated in Verticillium infected $F . \times$ ananassa in vitro plants. A critical step in plant defense is the sensing of the stress in order to respond in a quick and efficient manner. The perception of abiotic and biotic stress conditions initiates signaling cascades that open or close ion channels, activate or inactivate kinases, produce reactive oxygen species (ROS) and lead to the production of phytohormones.

In the present study, the ABA concentration in infected tissues exceeded the level in controls in leaves at $5 \mathrm{dpi}$ and in stems during the first $10 \mathrm{dpi}$ with a peak at 30 post inoculation revealing a crucial role in defense response. Such findings suggested that the ABA signaling pathway is a candidate for the control of systemic colonization by $V$. dahliae in strawberry. ABA has a prominent role during pathogen infection $[76,77]$, or is just involved in the perception of environmental stresses, particularly osmotic stresses [78]. The concentration of ABA increased in sugar beet leaves during Cercospora beticola fungus infection and elevated $\mathrm{ABA}$ concentrations were detected during colonization at 3 to $9 \mathrm{dpi}$ [79]. The role of ABA in disease resistance is discussed controversial as it depends on numerous factors, e.g. the type of the attacking pathogen, its entry point and way into the host, the timing of the defense response, and the plant tissue that is attacked by the pathogen. Thus, ABA has multiple effects depending on the environmental conditions and its exact role in plant pathogen interaction is still a matter of debate.

Another major hormone produced by plants is gibberellic acid (GA), which is also known to participate mainly in abiotic stress [80]. In the nineteenth century, GA was identified as being responsible for the excessive growth of rice seeds infected with the fungal pathogen Gibberella fujikuroi in Japan and only recently GA has been considered to be implicated in plant responses to pathogen attack and the role of GA in plant immunity has been studied. The outer capsid protein P2 of the rice dwarf virus (RDV) interacted with plant ent-kaurene oxidases, affecting the production of GA and the RDV infected rice plants showed a significant reduction in GA [81]. Those finding are consistent with the present study, which revealed that GA accumulated in comparison with non-infected tissues at $5 \mathrm{dpi}$ in leaves and stems and decreased during all the following infection days while in infected roots no significant GA level was detected during the 30 days of Verticillium infection. Thus, GA is part of the hormonal system used by plants in defense signaling pathways during pathogen colonization. The production of gibberellin by Verticillium species using dwarf mutant seedlings of Zea mays was investigated [82]. From 114 isolates of Verticillium grown on potato-carrot dextrose medium for 15 to 25 days, only 27 isolates produced "gibberellins" and 12 were identified as $V$. dahliae. Besides, treatment of sunflower with GA was able to prevent the stunting of plants seedlings inoculated with Verticillium, indicating that it may result from interference with normal GA activity. GA promotes degradation of DELLA proteins, which are negative regulators of growth and thus GA stimulates plant growth. In addition, DELLA proteins, which act also as negative regulators of GA signaling in Arabidopsis, modulate SA and JA dependent defense responses [83]. An Arabidopsis quadruple-DELLA mutant that lacked four DELLA genes was resistant to the biotrophic pathogens Pto DC3000 and Hyaloperonospora arabidopsis [83] but very susceptible to Botrytis cinerea, a necrotrophic fungus. Besides, GA is synthesized by the necrotrophic pathogens G. fujikuroi as a virulence factor to degrade DELLA proteins and to confer host susceptibility. In this case, GA is not only interfering with SA/ JA-dependent defenses but also by interfering the ROS balance and leading to death. Thus, the mechanism of 
action of GA in response to pathogen attack is still a topic of debate.

While ABA and GA are predominantly involved in abiotic stress, SA and JA are more responsible for the plant's reaction to biotic stress. In this study, SA accumulated in comparison with non-infected strawberry plants exclusively in leaves at $5 \mathrm{dpi}$ whereas JA exceeded the levels in the same infected tissue at 5 and $30 \mathrm{dpi}$. In stems, JA accumulated, in comparison with non-infected plants during the first 10 days post Verticillium infection and SA during the first 5 days while in infected roots only JA was identified at late stages (20-30 dpi). These results clearly demonstrate that both SA and JA defense signaling pathways are activated in strawberry plants during Verticillium colonization. The contents of SA and JA in F. $\times$ ananassa cv. Camarosa plantlets infected with Colletotrichum acutatum was studied [84]. The most significant SA and JA concentration in aerial tissues was also obtained after 5 dpi. A number of known components of both SA and JA-dependent defense pathways such as FaPR1-1 and FaGST1 (oxidative stress-responsive defense genes) were not significantly accumulated in strawberry during interaction with $C$. acutatum. Thus, only specific branches of both SA and JA-dependent defense pathways are affected by this pathogen in strawberry plants supporting the idea that this pathogen uses a molecular strategy to bypass the plant defense. Plants have complex defense mechanisms to withstand microbial and fungal pathogen attacks and hypersensitivity. The most powerful mode of resistance against pathogen attack is the accumulation of SA and certain PR proteins [85]. The xylem sap from hypocotyl and root of Brassica napus infected with $V$. longisporum contained high levels of SA that correlated to the amount of pathogen DNA and the degree of stunting [86]. SA is an import plant hormone implicated in the protection of plants against biotrophic and hemibiotrophic pathogens and plays a role in the establishment of systemic acquired resistance (SAR) [87]. Thus, SA is also involved in defense responses of plant tissues against Verticillium toxins [88]. In contrast, JA usually mediates protection against herbivorous insects and necrotrophic pathogens [89]. Verticillium species are hemibiotroph plant pathogenic fungi showing a necrotrophic phase during the late stages of infection. Therefore and as confirmed in this work, the plant SA defense signaling pathway is activated during the first biotrophic stage of Verticillium infection while the JA signaling pathway is activated in leaves, stems and roots also at the late phases. Briefly, the success of pathogen infection and growth depends on the balance of how fast the pathogen escapes the plant defenses and how quick the plant adapts the defense response. Besides, possible manipulations of the host's hormone status by the pathogen for its own benefit should be considered.

Because of the availability of suitable mutants in Arabidopsis thaliana, most of the experiments on phytohormones were conducted in this plant. One of the important regulatory components of SA signaling is the non-expressor of PR genes 1 (NPR1), which interacts with TGA (TGACG motif-binding protein family) transcription factors that are involved in the activation of SA-responsive PR genes [90]. Downstream of NPR1, several WRKY transcription factors (containing one or two WRKY protein domains) play important roles in the regulation of SA-dependent defense responses in plants [91, 92].

Interestingly, a rapid accumulation of JA during the first $11 \mathrm{~h}$ post inoculation (hpi), but not of SA, in phloem exudates of leaves challenged with an avirulent strain of Pseudomonas syringae and increased expression levels of JA biosynthetic genes suggested that JA could act as a mobile signal in Arabidopsis pathogen immunity [93]. Likewise, other researchers established that concentrations of JA increase in response to pathogen infection or tissue damage and that the expression of defense related genes is induced [94, 95]. Gene expression in response to JA is modulated among others by a tran scription factor JA insensitive 1/MYC2 (JIN1/MYC2) [96], members of the Apetala2/ethylene-responsive factor (AP2/ERF) family [97], an F-box coronatine insensitive protein 1 (COI1) [98], a plant defensin protein 1.2 (PDF 1.2) [99] and a repressor Jasmonate-ZIM-Domain protein (JAZ) [100]. A critical regulator mediating plant protection during $V$. dahliae infection appears to be a GbWRKY1 transcription factor, which activated JAZ1 expression in cotton [101]. Furthermore, the interaction between defense signaling pathways of SA and JA is an important mechanism for regulating defense responses against various types of pathogens. The Arabidopsis WRKY70 (transcription factor) [102, 103], MPK4 (Mitogen activated protein kinase 4) [104] and GRX480 (glutaredoxin) [105] have been found to regulate the antagonistic interaction between SA and JA-mediated defenses. In this work, JA levels in roots increased at late stages and those of SA were insignificant at this phase. This finding suggests an antagonistic relationship between the two pathways in strawberry. In addition, evidence of synergistic interactions between SA and JA defense pathways has been reported. MeJA and SA induced the transcription factor WRKY62 synergistically after pathogen inoculation [106] and activated the expression of some defense related genes [107].

Besides the aforementioned phytohormones, IAA was also analyzed in this work. Significant levels of IAA were 
detected in all infected samples. In leaves, IAA concentration increased gradually in comparison with the non-infected controls with a peak at $10 \mathrm{dpi}$ and then decreased until 30 dpi. IAA accumulated in comparison with the controls in stems during the first 5 days post Verticillium infection and exclusively in roots at $30 \mathrm{dpi}$. Such results suggested that IAA played also a crucial role in strawberry defense response toward Verticllium infection. A significant increase in IAA accumulation was also demonstrated in plant leaves infected with either Xcc (Arabidopsis-Xanthomonas campestris pv. campestris) or Pto (Pseudomonas syringae pv. tomato) with a maximal level occurring 3 to 4 days after infection [108]. Auxin responsive GH3 genes to play roles in the protection of Arabidopsis and rice. GH3.5 in Arabidopsis, is a bifunctional modulator during pathogen infection acting in both SA and auxin signaling [109]. In rice, overexpression of GH3.8 promoted resistance to the pathogen Xanthomonas oryzae pv oryzae (Xoo) in a SA and JA independent pathway [110]. GH3-8 impeded IAAinduced expansin production, which is probably reasonable for the resistance against Xoo. One of the mechanisms used by Xoo to infect plants is the IAA-stimulated local production of the expansin protein. In addition, IAA and SA interact antagonistically, thereby enhancing susceptibility to biotrophic pathogens [111]. Interestingly, transport inhibitor response protein 1 (TIR1), whose expression is repressed by $\mathrm{SA}$, is an IAA receptor and interacts with Aux/IAA proteins [112, 113].

This work represents the first study of the hormonal implication in strawberry $F . \times$ ananassa in response to Verticillium infection. Nevertheless, the fundamental molecular mechanisms and the role of those compounds toward pathogen attack in strawberry are not fully understood. How precisely the machinery of phytohormone signaling differs between Verticillium strains in strawberry, how does the plant modulate the level of phytohormones in response to numerous simultaneous pathogens attacks including Verticillium and which mechanisms may underlie a suitable control of signaling response to Verticillium infection, remain challenging questions for future investigations.

\section{Conclusions}

The gene expression of the twenty-one PR-10 genes revealed strong variation in transcript levels and a wide range of response. Nineteen $P R-10$ genes were clearly upregulated after Verticillium infection. The highest levels of expression were detected at early stage in roots and later time point for leaves consistent with the colonization of the plant. Analysis by LC-MS showed an accumulation of phytohormones in leaves, stems and roots already at $5 \mathrm{dpi}$ demonstrating a fast response of the $F . \times$ ananassa plants after pathogen infection and providing evidence of the involvement of phytohormones in plant defense signaling pathways. Antifungal metabolites accumulated at later periods after Verticillium infection. The work nicely illustrates the different defense strategies of the strawberry plant against attack by fungi.

\section{Methods \\ Propagation of in vitro plants}

For the propagation of $F . \times$ ananassa $\mathrm{cv}$. Elsanta in vitro plants, a revised Murashige and Skoog (MS) medium was used [114] and $20 \mathrm{~g} / \mathrm{l}$ of sucrose and $6.5 \mathrm{~g} / \mathrm{l}$ of agar were added. After adjusting the $\mathrm{pH}$ to 5.8 by $\mathrm{HCl}$ or $\mathrm{KOH}(1 \mathrm{M})$, the medium was autoclaved at $121^{\circ} \mathrm{C}$ for $20 \mathrm{~min}$. After cooling down the agar to $45-50^{\circ} \mathrm{C}$, the medium was supplemented with $50 \mathrm{mg} / \mathrm{l}$ of citric acid and ascorbic acid and finally dispensed $(30 \mathrm{~g})$ in 200 -ml-jars. Once the agar was solidified, the in vitro plants were transferred into the jars and the strawberry culture was maintained for around 6 weeks. F. $\times$ ananassa in vitro plants were grown in a dedicated room with a $16 \mathrm{~h}$ photoperiod. The average of the daytime temperature was $23.8 \pm 1.4{ }^{\circ} \mathrm{C}$ while during the night the temperature was around $22.0 \pm 1.5^{\circ} \mathrm{C}$.

\section{Infection with Verticillium}

$F$. $\times$ ananassa in vitro plants were artificially inoculated by the isolate $\mathrm{E} 650$ of $V$. dahliae, kindly provided by the Institute for Breeding Research on Horticultural Crops, Dresden. This isolate caused a weak to medium damage to the $F$. $\times$ ananassa cultivar used for this work. $V$. dahliae was cultured on potato dextrose agar using two layers of gauzes. The petri dishes were stored in the darkness for 3-4 weeks at $22^{\circ} \mathrm{C}$ (Additional file 1). One month later, the gauzes were immerged and swirled in $10 \mathrm{ml}$ of sterile distilled water. After filtration to remove hyphae, the conidia concentration was adjusted to $10^{6}$ spores $/ \mathrm{ml}$ using a Thoma hemocytometer. In vitro plants were inoculated directly on the agar medium by piercing the roots with the pipette tip at five different locations $\left(10^{6}\right.$ conidia $\left./ \mathrm{ml}\right)$.

Control plants were similarly inoculated with sterile water. Plants were kept in a growing chamber, harvested at 1, 5, 10, 20 and $30 \mathrm{dpi}$ and separated into leaves, stems, and roots. Five infected plants and five controls were taken at each time point. Leaf, root and stem samples were immediately frozen in liquid nitrogen and stored at $-80^{\circ} \mathrm{C}$. At all sampling time points, plants were visually assessed for the appearance of foliar symptoms using a $0-5$ scale according to [9]. 


\section{Primer design}

Specific primers were designed and verified using different bioinformatics tools (BioEdit/ Clustal 2.1/ Primer3/ OligoAnalyzer 3.1). Primer3 has many different input parameters, which can be controlled to define characteristics that allow the software to design primers suitable for qPCR analysis. For SYBR Green-based qPCR primer design, the following parameters were chosen: primer length of $18-30$ base pairs (bp), primer melting temperature $(\mathrm{Tm})$ between $58^{\circ} \mathrm{C}$ and $64^{\circ} \mathrm{C}$, and guanine-cytosine (GC) content of $20-80 \%$. Other criteria were the product size of less than $200 \mathrm{bp}$ and prevention of repeats in the nucleotide sequences to avoid mispriming (e.g. ACACACACAC). Specific primers for the 21 $P R-10$ isoforms are listed in Additional file 3. In order to check the gene specificity and to verify that the primers do not hybridize with another gene, each primer pair was blasted using in silico analysis. This was done by comparing the primer sequences to known gene databases, using the BLAST option. In addition, amplification products were subjected to melting curve analysis and single peaks indicated specificity.

\section{RNA extraction}

Total RNA was isolated as described [115] using the CTAB method. A $20 \mathrm{ml}$ aliquot of pre-heated extraction buffer was added to $1-2 \mathrm{~g}$ of lyophilized strawberry material. During the incubation of the mixture at $65^{\circ} \mathrm{C}$, Falcon tubes were inverted manually 3 times. Then, an equal volume of chloroform/isoamyl alcohol was added and the samples were again gently inverted by hand for $10 \mathrm{~min}$. After centrifugation at $12,000 \mathrm{rpm}\left(4^{\circ} \mathrm{C}\right)$, the supernatant was transferred to a new Falcon tube and a $1 / 3$ volume of $8 \mathrm{M} \mathrm{LiCl}$ was added to the reaction. RNA precipitation was carried out overnight at $4{ }^{\circ} \mathrm{C}$. After centrifugation at $12,000 \mathrm{rpm}$, for $30 \mathrm{~min}$ at $4{ }^{\circ} \mathrm{C}$, the RNA pellet was gently dissolved in $500 \mu \mathrm{l} 0.5 \%$ SDS. A second centrifugation step was following and the supernatant was then transferred to a new Eppendorf tube containing two volumes of $100 \%$ ethanol. The reaction was performed for $2 \mathrm{~h}$ at $-20^{\circ} \mathrm{C}$. After centrifugation of the precipitated RNA $\left(30 \mathrm{~min}, 4^{\circ} \mathrm{C}, 13,200 \mathrm{rpm}\right)$, the pellet was washed with $70 \%$ and the $100 \%$ ethanol. Subsequently, the pellet was air-dried and then dissolved in $50 \mu \mathrm{l}$ DEPC. The quality and quantity of RNA was determined using Nanodrop and 1\% agarose gel.

\section{Synthesis of CDNA}

One $\mu \mathrm{g}$ of DNase-treated RNA was reverse transcribed to cDNA using $1 \mu \mathrm{l}$ of random primers $(10 \mu \mathrm{M})$ and $1 \mu \mathrm{l}$ of $10 \mathrm{mM}$ dNTP in $20 \mu \mathrm{l}$ total volume. After a five minutes incubation time at $65^{\circ} \mathrm{C}$, the reaction mix was chilled on ice for $1 \mathrm{~min}$. A First strand buffer and RNase OUT recombinant RNase inhibitor were added to a nuclease-free-micro centrifuge tube. Later, one $\mu$ l of M-MLV RT was added after an incubation of $2 \mathrm{~min}$ at $37^{\circ} \mathrm{C}$. An incubation step at $25^{\circ} \mathrm{C}$ for $10 \mathrm{~min}$ was performed before synthesizing cDNA at $50^{\circ} \mathrm{C}$ for one hour. Then, the temperature was raised to $70^{\circ} \mathrm{C}$ to inactivate the reverse transcriptase and the cDNA was stored at $20^{\circ} \mathrm{C}$.

\section{Quantitative real time PCR (qPCR)}

Quantitative real time PCR analyses were performed using the StepOne Realtime PCR Instrument and Software (Applied Biosystems, Darmstadt, Germany). A Master Mix for each PCR run was prepared with SYBR Green (Applied Biosystems). The amplification was carried out as follows in $20 \mu \mathrm{l}$ total volume: $10 \mu \mathrm{l}$ Fast SYBR Green Master Mix, $10 \mu \mathrm{M}$ forward Primer, $10 \mu \mathrm{M}$ reverse Primer and $2 \mu \mathrm{l}$ of the template (cDNA). The PCR amplification program was optimized for 40 cycles using the following standard thermal program: $95^{\circ} \mathrm{C}$ for 10 min, then $95^{\circ} \mathrm{C}$ for $15 \mathrm{~s}$ and $60^{\circ} \mathrm{C}$ for $1 \mathrm{~min}$ ( 40 cycles), followed by $95^{\circ} \mathrm{C}$ for $15 \mathrm{~s}, 60^{\circ} \mathrm{C}$ for $1 \mathrm{~min}$ and $95^{\circ} \mathrm{C}$ for $15 \mathrm{~s}$. The amplification was carried out in a 96-well reaction plate (Applied Biosystems) and all samples were amplified in at least three technical replicates. A cDNA dilution of $1 / 20$ for the target gene and $1 / 8000$ for the housekeeping gene were found enough sensitive for the gene quantification studies. The $\mathrm{Ct}$ values (threshold cycle value) of each $P R-10$ gene were normalized to 1 $\mathrm{dpi}$ in control stems using the $\mathrm{Ct}$ value of the strawberry FaRIB413 gene which is corresponding to an internal RNA interspacer (16S-23S). The fold change of gene expression $2^{-\Delta \Delta \mathrm{Ct}}$ was calculated according to [116].

\section{LC-MS analysis}

For this approach an internal standard, containing $50 \mathrm{mg}$ of biochanin A and $50 \mathrm{mg}$ 4-methylumbelliferyl- $\beta-\mathrm{D}$ glucuronide which were dissolved by sonication for 10 min in $250 \mathrm{ml}$ methanol, was prepared. For the extraction procedure, $50 \mathrm{mg}$ of lyophilized tissues (leaves, roots and stems) of infected and non-infected strawberry plants were mixed with $250 \mu \mathrm{l}$ of internal standard and $250 \mu \mathrm{l}$ of methanol. Samples were vortexed for $1 \mathrm{~min}$, sonicated for $10 \mathrm{~min}$ and centrifuged also for $10 \mathrm{~min}$ at $13,200 \mathrm{rpm}$. Supernatant was taken into a new Eppendorf tube and the pellet was extracted again with $500 \mu \mathrm{l}$ of methanol. Then, both supernatants were combined and treated with Speed-Vac System for $2-3 \mathrm{~h}$ to evaporate the methanol. The dried pellet was re-suspended in $35 \mu \mathrm{l}$ LC-MS quality water, vortexed, sonicated and centrifuged twice at max speed. Finally, the clear supernatant was taken into an LC-MS vial with micro-insert and analyzed by LC-UV-ESI-MS. The accumulation of metabolites in leaves, stems and roots of infected and non-infected in vitro plants was tested referring to their 
retention time and fragmentation pattern by the means of QuantAnalysis software. This tool was used for quantification and results were normalized against the internal standard (biochanin A). The accumulation of the below mentioned metabolites is designed as the relative concentration (Rel. conc.) which is expressed in mg-equ./g dry weight of the internal standard biochanin A in freeze-dried strawberry tissues (leaves, stems and roots).

Abscisic acid (ABA, $264.32 \mathrm{~g} / \mathrm{mol}$ ), salicylic acid (SA, $138.12 \mathrm{~g} / \mathrm{mol}$ ), jasmonic acid (JA, $210.27 \mathrm{~g} / \mathrm{mol}$ ), gibberellic acid (GA, $346.47 \mathrm{~g} / \mathrm{mol}$ ) and indole acetic acid (IAA, $175.19 \mathrm{~g} / \mathrm{mol}$ ) were eluted at $37.9 \mathrm{~min}, 35.5 \mathrm{~min}$, $39.1 \mathrm{~min}, 30.8 \mathrm{~min}$ and $33.3 \mathrm{~min}$, respectively. The retention times were confirmed by analyses of authentical reference materials.

\section{Statistical analysis}

The statistical analysis was carried out using the statistical program SAS (SAS Institute Inc., Cary, USA). A one-way analysis of variance (ANOVA) was performed for each inoculation day and the mean values of the relative expression level of the 21 genes were analyzed by the Tukey test. The significance level was $p \leq 0.05$.

\section{Writing guideline}

Symbols for gene names are denoted in italic (e.g., $P R$-10.06) while symbols for protein names are not italicized (e.g., PR-10.06).

\section{Additional files}

Additional file 1: Culture of Verticillium dahliae in potato dextrose agar medium. The bottom (right) and the top (left) of the Petri dish represent the evolution of the culture after 3-4 weeks. (PPTX $548 \mathrm{~kb}$ )

Additional file 2: PR-10 nomenclature and gene number (PPTX $34 \mathrm{~kb}$ )

Additional file 3: Primers of the 21 PR-10 isoforms used for $\mathrm{qPCR}$ analysis. (PPTX $44 \mathrm{~kb}$ )

Additional file 4: Phylogenetic tree of $P R-10$ genes and summary of the expression profile of the $21 P R-10$ isoforms in untreated leaves, stems and roots of in vitro cultivated $F$. $x$ ananassa plants (green bars) and infected tissues with $V$. dahliae (red bars) at various time points post (days) pathogen inoculation. $\mathrm{PPCR}$ using specific primers for $P R-10$ genes and the reference gene was used for the expression analysis. (PPTX $238 \mathrm{~kb}$ )

\section{Abbreviations}

ABA: Abscisic acid; BLAST: Basic Local Alignment Search Tool; dpi: Days post infection; GA: Gibberellic acid; GSH: Glutathione; GSSH: Oxidized glutathione; IAA: Indole acetic acid; JA: Jasmonic acid; LC-MS: Liquid chromatographymass spectrometry; PR-10: Pathogenesis-related protein family 10; qPCR: Quantitative polymerase chain reaction; RDV: Rice dwarf virus: ROS: Reactive oxygen species; SA: Salicylic acid; Tm: Melting temperature

\section{Acknowledgements}

We thank Hannelore Meckl for helping to propagate the in vitro plants and Thomas Hoffmann for the technical assistance with the LC-MS analysis.

\section{Funding}

This work was supported by the Deutscher Akademischer Austauschdienst (DAAD) [grant no. 57076385 to F.B.]. F.B. received a scholarship from DAAD to complete her doctorate in Germany. The funding body was not involved in the design of the study and collection, analysis, and interpretation of data and in writing the manuscript.

\section{Availability of data and materials}

The datasets used and/or analysed during the current study are available from the corresponding author on reasonable request.

\section{Author's contributions}

F.B. designed and performed the experiments and wrote the manuscript, R.H. performed the experiments and W.S. planed the experiments, supervised the study, and corrected the manuscript. All authors read and approved the final manuscript.

Ethics approval and consent to participate

Not applicable

Consent for publication

Not applicable

\section{Competing interests}

The authors declare that they have no competing interests.

\section{Publisher's Note}

Springer Nature remains neutral with regard to jurisdictional claims in published maps and institutional affiliations.

Received: 6 August 2018 Accepted: 14 March 2019

Published online: 05 April 2019

\section{References}

1. Pegg GF, Brady BL. Verticillium wilts. Wallingford, UK: CABI Publishing; 2002.

2. Inderbitzin P, Bostock RM, Davis RM, Usami T, Platt HW, Subbarao KV. Phylogenetics and taxonomy of the fungal vascular wilt pathogen Verticillium, with the descriptions of five new species. PLoS One. 2011;6: e28341.

3. Zare R, Gams W, Starink-Willemse M, Summerbell RC. Gibellulopsis, a suitable genus for Verticillium nigrescens, and Musicillium, a new genus for V. Theobromae. Nova Hedwigia. 2007;85:463-89.

4. Hawksworth DL, Talboys PW. Verticillium dahliae. CMI Descr Pathog Fungi Bact. 1970:255-9.

5. Gams W, Zare R, Summerbell RC. Proposal to conserve the generic name Verticillium (anamorphic ascomycetes) with a conserved type. Taxon. 2005; 54:179.

6. Klosterman SJ, Atallah ZK, Vallad GE, Subbarao KV. Diversity, pathogenicity, and management of Verticillium species. Annu Rev Phytopathol. 2009:47:39-62.

7. Subbarao KV, Kabir Z, Martin FN, Koike ST. Management of soilborne diseases in strawberry using vegetable rotations. Plant Dis. 2007;91:964-72.

8. Mol L. Effect of plant roots on the germination of microsclerotia of Verticillium dahliae. Eu J Plant Pathol. 1995;101:679-85.

9. Bishop CD, Cooper RM. An ultrastructural study of root invasion in three vascular wilt diseases. Physiol Plant Pathol. 1983;22:15-27.

10. Chen $P$, Lee $B$, Robb J. Tolerance to a non-host isolate of Verticillium dahliae in tomato. Physiol Mol Plant Pathol. 2004;64:283-91.

11. Heinz R, Lee SW, Saparno A, Nazar RN, Robb J. Cyclical systemic colonization in Verticillium-infected tomato. Physiol Mol Plant Pathol. 1998;52:385-96.

12. Wilhelm S. Longevity of the Verticillium wilt fungus in the laboratory and in the field. Phytopathology. 1955;45:180-1.

13. Fradin EF, Thomma BP. Physiology and molecular aspects of Verticillium wilt diseases caused by V. Dahliae and V. Albo-atrum. Mol Plant Pathol. 2006;7: $71-86$.

14. Mc Fadden HG, Chapple R, Feyter RDE, Dennis E. Expression of pathogenesis-related genes in cotton stems in response to infection by Verticillium dahliae. Physiol Mol Plant Pathol. 2001;58:119-31.

15. Chen L, Na Sun N, Wang J, Ling H, Zhang L, Zuo K. Functional analysis of a wilt fungus inducible PR10-1 gene from cotton. Am J Plant Sci. 2013:04: 417-26. 
16. Fernandes H, Michalska K, Sikorski M, Jaskolski M. Structural and functional aspects of PR-10 proteins. FEBS J. 2013;280:1169-99.

17. Calcante A, Mena A, Mazzetto F. Optical devices evaluation for diagnosis of Plasmopara viticola on vine. Agri Eng Int CIGR Journal. 2011;13:2.

18. Shulaev V, Sargent DJ, Crowhurst RN, Mockler TC, Folkerts O, Delcher AL, Jaiswal P, Mockaitis K, Liston A, Mane SP, Burns P, Davis TM, Slovin JP, Bassil N, Hellens RP, Evans C, Harkins T, Kodira C, Desany B, Crasta OR, Jensen RV, Allan AC, Michael TP, Setubal JC, Celton JM, Rees DJ, Williams KP, Holt SH, Ruiz Rojas JJ, Chatterjee M, Liu B, Silva H, Meisel L, Adato A, Filichkin SA, Troggio M, Viola R, Ashman TL, Wang H, Dharmawardhana P, Elser J, Raja R, Priest HD, Bryant DW Jr, Fox SE, Givan SA, Wilhelm LJ, Naithani S, Christoffels A, Salama DY, Carter J, Lopez Girona E, Zdepski A, Wang W, Kerstetter RA, Schwab W, Korban SS, Davik J, Monfort A, Denoyes-Rothan B, Arus P, Mittler R, Flinn B, Aharoni A, Bennetzen JL, Salzberg SL, Dickerman AW, Velasco R, Borodovsky M, Veilleux RE, Folta KM. The genome of woodland strawberry (Fragaria vesca). Nat Genet. 2011;43:109-18.

19. Muñoz C, Hoffmann T, Escobar NM, Ludemann F, Botella MA, Valpuesta V, Schwab W. The strawberry fruit Fra a allergen functions in flavonoid biosynthesis. Mol Plant. 2010;3:113-24.

20. Floerl S, Druebert C, Majcherczyk A, Karlovsky P, Kues U, Polle A. Defence reactions in the apoplastic proteome of oilseed rape (Brassica napus var. napus) attenuate Verticillium longisporum growth but not disease symptoms. BMC Plant Biol. 2008;8:129.

21. Klosterman SJ, Anchieta A, Garcia-Pedrajas MD, Maruthachalam K, Hayes RJ, Subbarao KV. SSH reveals a linkage between a senescence-associated protease and Verticillium wilt symptom development in lettuce (Lactuca sativa). Physiol Mol Plant Pathol. 2011;76:48-58.

22. Millet YA, Danna CH, Clay NK, Songnuan W, Simon MD, Werck-Reichhart D Ausubel FM. Innate immune responses activated in Arabidopsis roots by microbe-associated molecular patterns. Plant Cell. 2010;22:973-90.

23. Okubara PA, Paulitz TC. Root defense responses to fungal pathogens: a molecular perspective. Plant Soil. 2005;274:215-26.

24. Pantelides IS, Tjamos SE, Paplomatas EJ. Ethylene perception via ETR1 is required in Arabidopsis infection by Verticillium dahliae. Mol Plant Pathol. 2010;11:191-202.

25. Tjamos SE, Flemetakis E, Paplomatas EJ, Katinakis P. Induction of resistance to Verticillium dahliae in Arabidopsis thaliana by the biocontrol agent K-165 and pathogenesis- related proteins gene expression. Mol Plant-Microbe Interact. 2005;18:555-61.

26. Johansson A, Staal J, Dixelius C. Early responses in the ArabidopsisVerticillium longisporum pathosystem are dependent on NDR1, JA- and ETassociated signals via cytosolic NPR1 and RFO1. Mol Plant-Microbe Interact. 2006;19:958-69.

27. Iven T, Stefanie König S, Singh S, Braus-Stromeyer SA, Matthias Bischoff M, Tietze LF, Braus GH, Lipka V, Feussner I, Dröge-Laser W. Transcriptional activation and production of tryptophan-derived secondary metabolites in Arabidopsis roots contributes to the defense against the fungal vascular pathogen Verticillium longisporum. Mol Plant. 2012;5:1389-402.

28. Vander Molen $\mathrm{GE}$, Beckman CH, Rodehorst E. Vascular gelation: a general response phenomenon following infection. Physiol Plant Pathol. 1977;11:95-100.

29. Koistinen KM, Hassinen VH, Gynther PAM, Lehesranta SJ, Keinänen SI, Kokko HI, Oksanen EJ, Tervahauta AI, Seppo Auriola S, Kärenlampi SO. Birch PR-10c is induced by factors causing oxidative stress but appears not to confer tolerance to these agents. New Phytol. 2002;155:381-91.

30. Gold J, Robb J. The role of the coating response in Craigella tomatoes infected with Verticillium dahliae races 1 and 2. Physiol Mol Plant Pathol. 1995:47:141-57.

31. Cregeen S, Radisek S, Mandelc S, Turk B, Stajner N, Jakse J, Javornik B. Different gene expressions of resistant and susceptible hop cultivars in response to infection with a highly aggressive strain of Verticillium alboatrum. Plant Mol Biol. 2015;33:689-704.

32. Fradin EF, Zhang Z, Ayala JCJ, Castroverde CDM, Nazar RN, Robb J, Liu CM, Thomma B. Genetic dissection of Verticillium wilt resistance mediated by tomato Ve1. Plant Physiol. 2009;150:320-32.

33. Robb J, Powell DA, Street PFS. Time course of wall-coating secretion in Verticilium-infected tomatoes. Physiol Mol Plant Pathol. 1987;31:217-26.

34. Street PFS, Robb J, Ellis BE. Secretion of vascular coating components by xylem parenchyma cells of tomatoes infected with Verticillium albo-atrum. Protoplasma. 1986;132:1-11.

35. Robb J, Lee SW, Mohan R, Kolattukudy PE. Chemical characterization of stress-induced vascular coating in tomato. Plant Physiol. 1991;97:528-36.
36. van Esse HP, Fradin EF, de Groot PJ, de Wit PJ, Thomma BP. Tomato transcriptional responses to a foliar and a vascular fungal pathogen are distinct. Mol Plant-Microbe Interact. 2009;22:245-58.

37. Shaw DV, Gordon TR, Hansen J, Kirkpatrick SC. Relationship between the extent of colonization by Verticillium dahliae and symptom expression in strawberry (Fragaria $\times$ ananassa) genotypes resistant to verticillium wilt. Plant Pathol. 2010;59:376-81.

38. Robb J, Lee B, Nazar RN. Gene suppression in a tolerant tomato-vascular pathogen interaction. Planta. 2007;226:299-309.

39. Shaw DV, Gubler WD, Larson KD, Hansen J. Genetic variation for field resistance to Verticillium dahliae evaluated using genotypes and segregating progenies of California strawberries. J Am Soc Hortic Sci. 1996;121:625-8.

40. Żebrowska J, Hortyński J, Cholewa T, Honcz K. Resistance to Verticillium dahliae (Kleb.) in the strawberry breeding lines. Commun Agric Appl Biol Sci. 2006;71:1031-6.

41. Żebrowska J. Efficacy of resistance selection to Verticillium wilt in strawberry (Fragaria x ananassa Duch.) tissue. Acta Agrobot. 2011;64:3-12.

42. Orlando R, Magro P, Rugini E. Pectic enzymes as a selective pressure for in vitro recovery of strawberry plants with fungal disease resistance. Plant Cell. 1997;16:272-6.

43. Damiano C, Monticelli S, Frattarelli A, Nicolini S, Corazza L. Somaclonal variability and in vitro regeneration of strawberry. Acta Hortic. 1997:447:87-94.

44. Toyoda H, Horikoshi K, Yamano Y, Ouchi S. Selection of Fusarium wilt disease resistance from regenerants derived from callus of strawberry. Plant Cell. 1991;10:167-70.

45. Maas JL, Zhong L, Galletta GJ. In vitro screening of strawberry plant and root cultures for resistance to Phytophthora fragariae and P.Cactorum. Acta Hortic. 1993;348:496-9.

46. Sowik I, Bielenin A, Michalczuk L. In vitro testing of strawberry resistance to Verticillium dahliae and Phytophthora cactorum. Sci Hortic. 2001;88:31-40.

47. Jain SM. Tissue culture-derived variation in crop improvement. Euphytica. 2001;118:153-66.

48. Sowik I, Michalczuk L, Wójcik D. A method for in vitro testing strawberry susceptibility to Verticillium. J Fruit Ornam Plant Res. 2008;16:111-21.

49. Yamamoto M, Nakatsuka S, Otani H, Kohmoto K, Nishimura S. (+)-Catechin acts as an infection-inhibiting factor in strawberry leaf. Phytopathology. 2000;90:595-600.

50. Puhl I, Treutter D. Ontogenetic variation of catechin biosynthesis as basis for infection and quiescence of Botrytis cinerea in developing strawberry fruits. J Plant Dis Protect. 2008;115:247-51.

51. Blair AC, Hanson BD, Brunk GR, Marrs RA, Westra P, Nissen SJ, Hufbauer RA. New techniques and findings in the study of a candidate allelochemical implicated in invasion success. Ecol Lett. 2005;8:1039-47.

52. Inderjit KR, Kaur S, Callaway RM. Impact of $( \pm)$-catechin on soil microbial communities. Commun Integr Biol. 2009;2:127-9.

53. Veluri R, Weir TL, Bais HP, Stermitz FR, Vivanco JM. Phytotoxic and antimicrobial activities of catechin derivatives. J Agric Food Chem. 2004;52: 1077-82.

54. Bais HP, Walker TS, Stermitz FR, Hufbauer RA, Vivanco JM. Enantiomericdependent phytotoxic and antimicrobial activity of $( \pm)$-catechin. A rhizosecreted racemic mixture from spotted knapweed. Plant Physiol. 2002; 128:1173-9.

55. Prusky D, Kobiler I, Jacoby B, Sims JJ, Midland SL. Inhibitors of avocado lipoxygenase: their possible relationship with the latency of Colletotrichum gloeosporioides. Physiol Plant Pathol. 1985;27:269-79.

56. Wattad C, Dinoor A, Prusky D. Purification of pectate lyase produced by Colletotrichum gloeosporioides and its inhibition by epicatechin: a possible factor involved in the resistance of unripe avocado fruits to anthracnose. Mol Plant-Microbe Interact. 1994;7:293-7.

57. Feucht W, Treutter D. The role of flavan-3-ols and proanthocyanidins in plant defense. In: Principles and Practices in Plant Ecology: Allelochemical Interactions. Ed. by Inderjit, Dakshini KMM, Foy CL. Boca Raton: CRC Press; 1999. p. 307-338.

58. López-Ráez JA. Flors V, García JM,1 and Pozo MJ. AM symbiosis alters phenolic acid content in tomato roots. Plant Signal Behav. 2010;5:1138-40.

59. Wiese MV, Devay JE. Growth regulator changes in cotton associated with defoliation caused by Verticillium albo-atrum. Plant Physiol. 1970:45:304-9.

60. El-Bebany ALR, Daayf F. Differential accumulation of phenolic compounds in potato in response to weakly and highly aggressive isolates of Verticillium dahliae. Can J Plant Pathol. 2013;35:232-40. 
61. Veloso J, Alabouvette C, Olivain C, Flors V, Pastor V, Garcia T, Diaz J. Modes of action of the protective strain Fo47 in controlling verticillium wilt of pepper. Plant Pathol. 2016;65:997-1007.

62. Liu Y, Zhang N, Qiu M, Feng H, Vivanco JM, Shen Q, Zhang R. Enhanced rhizosphere colonization of beneficial bacillus amyloliquefaciens SQR9 by pathogen infection. FEMS Microbiol Lett. 2014;353:49-56.

63. Kamilova F, Kravchenko LV, Shaposhnikov Al, Azarova T, Makarova N, Lugtenberg B. Organic acids, sugars, and L-tryptophane in exudates of vegetables growing on stonewool and their effects on activities of rhizosphere bacteria. Mol Plant-Microbe Interact. 2006;19:250-6.

64. Kamilova F, Kravchenko LV, Shaposhnikov Al, Makarova N, Lugtenberg B. Effects of the tomato pathogen Fusarium oxysporum f. Sp radicis-lycopersici and of the biocontrol bacterium Pseudomonas fluorescens WCS365 on the composition of organic acids and sugars in tomato root exudate. Mol PlantMicrobe Interact. 2006;19:1121-6.

65. Kim MS, Jin JS, Kwak YS, Hwang GS. Metabolic response of strawberry (Fragaria $X$ Ananassa) leaves exposed to the angular leaf spot bacterium (Xanthomonas Fragariae). J Agric Food Chem. 2016;64:1889-98.

66. Ishihara A, HashimotoY TC, Dubouzet JG, Nakao T, Matsuda F, Nishioka T, Miyagawa $\mathrm{H}$, Wakasa $\mathrm{K}$. The tryptophan pathway is involved in the defense responses of rice against pathogenic infection via serotonin production. Plant J. 2008:54:481-95.

67. Ball L, Accotto GP, Bechtold U, Creissen G, Funck D, Jimenez A, Kular B, Leyland N, Mejia-Carranza J, Reynolds H, Karpinski S, Mullineaux PM. Evidence for a direct link between glutathione biosynthesis and stress defense gene expression in Arabidopsis. Plant Cell. 2004;16:2448-62.

68. Mauch F, Dudler R. Differential induction of distinct glutathione-S-transferases of wheat by xenobiotics and by pathogen attack. Plant Physiol. 1993;102:1193-201.

69. Noctor G, Arisi ACM, Jouanin L, Kunert KJ, Rennenberg H, Foyer $\mathrm{CH}$. Glutathione: biosynthesis, metabolism and relationship to stress tolerance explored in transformed plants. J Exp Bot. 1998;49:623-47.

70. Winterbourn CC, Metodiewa D. Reactivity of biologically important thiol compounds with superoxide and hydrogen peroxide. Free Radic Biol Med. 1999; 27:322-8.

71. Edwards R, Blount JW, Dixon RA. Glutathione and elicitation of the phytoalexin response in legume cell cultures. Planta. 1991;184:403-9.

72. Gönner M. Schlösser E. Oxidative stress in interactions between Avena sativa L. and Drechslera spp. Physiol Mol Plant Pathol. 1993;42:221-34.

73. May MJ, Hammond-Kosack KE, Jones J. Involvement of reactive oxygen species, glutathione metabolism, and lipid peroxidation in the (Cf-genedependent defense response of tomato cotyledons induced by racespecific elicitors of Cladosporium fulvum. Plant Physiol 1996;110:1367-1379.

74. Vanacker H, Foyer C, Carver TLW. Changes in apoplast antioxidants induced by powdery mildew attack in oat genotypes with race non-specific resistance. Planta. 1999;208:444-52.

75. Fodor J, Gullner G, Adam AL, Barna B, Komives T, Kiraly Z. Local and systemic responses of antioxidants to tobacco mosaic virus infection and to salicylic acid in tobacco. (role in systemic acquired resistance). Plant Physiol. 1997;114:1443-51.

76. Flors V, Ton J, van Doorn R, Jakab G, García Agustín P, Mauch-Mani B. Interplay between JA, SA and ABA signalling during basal and induced resistance against Pseudomonas syringae and Alternaria brassicicola. Plant J. 2008;54:81-92

77. Ton J, Flors V, Mauch-Mani B. The multifaceted role of ABA in disease resistance. Trends Plant Sci. 2009;14:310-7.

78. Cramer GR, Urano K, Delrot S, Pezzotti M, Shinozaki K. Effects of abiotic stress on plants: a systems biology perspective. BMC Plant Biol. 2011;11:163-77.

79. Schmidt K, Pflugmacher M, Klages S, Mäser A, Mock A, Stahl DJ. Accumulation of the hormone abscisic acid (ABA) at the infection site of the fungus Cercospora beticola supports the role of $A B A$ as a repressor of plant defence in sugar beet. Mol Plant Pathol. 2008;9:661-73.

80. Colebrook EH, Thomas SG, Phillips AL, Hedden P. The role of gibberellin signalling in plant responses to abiotic stress. J Exp Biol. 2014;217:67-75.

81. Zhu S, Gao F, Cao X, Chen M, Ye G, Wei C, Li Y. The rice dwarf virus P2 protein interacts with ent-kaurene oxidases in vivo, leading to reduced biosynthesis of gibberellins and rice dwarf symptoms. Plant Physiol. 2005; 139:1935-45.

82. Aubé C, Sackston WE. Distribution and prevalence of Verticillium species producing substances with gibberellin-like biological. Can J Bot. 1965;43:1335-42.

83. Navarro L, Bari R, Achard P, Lison P, Nemri A, Harberd NP, Jones JD. DELLAs control plant immune responses by modulating the balance of jasmonic acid and salicylic acid signaling. Curr Biol. 2008;18:650-5.
84. Amil-Ruiz F, Garrido-Gala J, Gadea J, Blanco-Portales R, Muñoz-Mérida A, Trelles O, de Los SB, Arroyo FT, Aguado-Puig A, Romero F, Mercado JÁ, Pliego-Alfaro F, Muñoz-Blanco J, Caballero JL. Partial activation of SA- and JA-defensive pathways in strawberry upon Colletotrichum acutatum interaction. Front Plant Sci. 2016;7:1036.

85. Song J, Bradeen JM, Naess SK, Raasch JA, Wielgus SM, Haberlach GT, Liu J, Kuang H, Austin-Phillips S, Buell CR, Helgeson JP, Jiang J. Gene RB cloned from Solanum bulbocastanum confers broad spectrum resistance to potato late blight. Proc Natl Aca Sci U S A. 2003;100:9128-33.

86. Ratzinger A, Riediger N, von Tiedemann A, Karlovsky P. Salicylic acid and salicylic acid glucoside in xylem sap of Brassica napus infected with Verticillium longisporum. J Plant Res. 2009;122:571-9.

87. Grant M, Lamb C. Systemic immunity. Curr Opin Plant Biol. 2006;9:414-20.

88. Zhen XH, Li YZ. Ultrastructural changes and location of beta-1,3-glucanase in resistant and susceptible cotton callus cells in response to treatment with toxin of Verticillium dahliae and salicylic acid. J Plant Physiol. 2004;161:1367-77.

89. Glazebrook J. Contrasting mechanisms of defence against biotrophic and necrotrophic pathogens. Annu Rev Phytopathol. 2005;43:205-27.

90. Dong X. NPR1, all things considered. Curr Opin Plant Biol. 2004;7:547-52.

91. Eulgem T, Somssich IE. Networks of WRKY transcription factors in defence signaling. Curr Opin Plant Biol. 2007;10:366-71.

92. Wang D, Amornsiripanitch N, Dong X. A genomic approach to identify regulatory nodes in the transcriptional network of systemic acquired resistance in plants. PLoS Pathog. 2006;2:e123.

93. Truman W, Bennett MH, Kubigsteltig I, Turnbull C, Grant RM. Arabidopsis systemic immunity uses conserved defence signaling pathways and is mediated by jasmonates. Proc Natl Aca Sci. 2007;104:1075-80.

94. Lorenzo O, Solano R. Molecular players regulating the jasmonate signaling network. Curr Opin Plant Biol. 2005;8:532-40.

95. Wasternack C. Jasmonates: an update on biosynthesis, signal transduction and action in plant stress response, growth and development. Ann Bot. 2007:100:681-97.

96. Lorenzo O, Chico JM, Sánchez-Serrano JJ, Solano R. JASMONATEINSENSITIVE1 encodes a MYC transcription factor essential to discriminate between different jasmonate-regulated defence responses in Arabidopsis. Plant Cell. 2004;16:1938-50.

97. Mizoi J, Shinozaki K, Yamaguchi-Shinozaki K. AP2/ERF family transcription factors in plant abiotic stress responses. Biochim Biophys Acta. 1819;2012:86-96.

98. Xie DX, Feys BF, James S, Nieto-Rostro M, Turner JG. COl1: an Arabidopsis gene required for jasmonate-regulated defense and fertility. Science. 1998; 280:1091-4.

99. Brown RL, Kazan K, McGrath KC, Maclean DJ, Manners JM. A role for the GCC-box in jasmonate-mediated activation of the PDF1.2 gene of Arabidopsis. Plant Physiol. 2003;132:1020-32.

100. Chini A, Fonseca S, Fernandez G, Adie B, Chico JM, Lorenzo O, GarcíaCasado G, López-Vidriero I, Lozano FM, Ponce MR, Micol JL, Solano R. The JAZ family of repressors is the missing link in jasmonate signalling. Nature. 2007;448:666-71.

101. Li C, He X, Luo X, Xu L, Liu L, Min L, Jin L, Zhu L, Zhang X. Cotton WRKY1 mediates the plant defense-to-development transition during infection of cotton by Verticillium dahliae by activating JASMONATE-ZIM-DOMAIN1 expression. Plant Physiol. 2014;166:2179-94.

102. Li J, Brader G, Palva ET. The WRKY70 transcription factor: a node of convergence for jasmonate-mediated and salicylatemediated signals in plant defence. Plant Cell. 2004;16:319-31.

103. Li J, Brader G, Kariola T, Palva ET. WRKY70 modulates the selection of signaling pathways in plant defence. Plant J. 2006;46:477-91.

104. Brodersen P, Petersen M, Bjørn Nielsen H, Zhu S, Newman MA, Shokat KM, Rietz S, Parker J, Mundy J. Arabidopsis MAP kinase 4 regulates salicylic acidand jasmonic acid/ethylene-dependent responses via EDS1 and PAD4. Plant J. 2006:47:532-46.

105. Meyer Y, Siala W, Bashandy T, Riondet C, Vignols F, Reichheld JP. Glutaredoxins and thioredoxins in plants. Biochim Biophys Acta. 1783;2008: 589-600.

106. Mao P, Duan M, Wei C, Li Y. WRKY62 transcription factor acts downstream of cytosolic NPR1 and negatively regulates jasmonate-responsive gene expression. Plant Cell Physiol. 2007;48:833-42.

107. Mur LAJ, Kenton P, Atzorn R, Miersch O, Wasternack C. The outcomes of concentration specific interactions between salicylate and jasmonate signaling include synergy, antagonism, and oxidative stress leading to cell death. Plant Physiol. 2006;140:249-62. 
108. O'Donnell PJ, Schmelz EA, Moussatche P, Lund ST, Jones JB, Klee HJ. Susceptible to intolerance- - a range of hormonal actions in a susceptible Arabidopsis pathogen response. Plant J. 2003;33:245-57.

109. Zhang Z, Li Q, Li Z, Staswick PE, Wang M, Zhu Y, He Z. Dual regulation role of $\mathrm{GH} 3.5$ in salicylic acid and auxin signaling during ArabidopsisPseudomonas syringae interaction. Plant Physiol. 2007;145:450-64.

110. Ding X, Cao Y, Huang L, Zhao J, Xu C, Li X, Wang S. Activation of the indole-3-acetic acid-amido synthetase GH3-8 suppresses expansin expression and promotes salicylate-and jasmonate-independent basal immunity in rice. Plant Cell. 2008;20:228-40.

111. Kazan K, Manners JM. Linking development to defense: auxin in plantpathogen interactions. Trends Plant Sci. 2009;14:373-82.

112. Dharmasiri N, Dharmasiri S, Estelle M. The F-box protein TIR1 is an auxin receptor. Nat. 2005;435:441-5.

113. Kepinski S, Leyser O. The Arabidopsis F-box protein TIR1 is an auxin receptor. Nature. 2005;435:446-51.

114. Murashige T, Skoog F. A revised medium for rapid growth and bio assays with tobacco tissue cultures. Physiol Plant. 1962;15:473-97.

115. Liao Z, Chen M, Guo L, Gong Y, Tang F, Sun X, Tang K. Rapid isolation of high-quality total RNA from Taxus and ginkgo. Prep Biochem Biotechnol. 2004;34:209-14.

116. Livak KJ, Schmittgen TD. Analysis of relative gene expression data using real-time quantitative PCR and the 2 (-Delta Delta C (T)) method. Methods. 2001;25:402-8

Ready to submit your research? Choose BMC and benefit from:

- fast, convenient online submission

- thorough peer review by experienced researchers in your field

- rapid publication on acceptance

- support for research data, including large and complex data types

- gold Open Access which fosters wider collaboration and increased citations

- maximum visibility for your research: over $100 \mathrm{M}$ website views per year

At BMC, research is always in progress.

Learn more biomedcentral.com/submissions 